\title{
Grensoverschrijdende fiscale organisatie van pensioen
}

Citation for published version (APA):

Bollen-Vandenboorn, A. H. H. (2016). Grensoverschrijdende fiscale organisatie van pensioen. Maastricht University. https://doi.org/10.26481/spe.20161216ab

Document status and date:

Published: 16/12/2016

DOI:

10.26481/spe.20161216ab

Document Version:

Publisher's PDF, also known as Version of record

Document license:

Unspecified

\section{Please check the document version of this publication:}

- A submitted manuscript is the version of the article upon submission and before peer-review. There can be important differences between the submitted version and the official published version of record.

People interested in the research are advised to contact the author for the final version of the publication, or visit the DOI to the publisher's website.

- The final author version and the galley proof are versions of the publication after peer review.

- The final published version features the final layout of the paper including the volume, issue and page numbers.

Link to publication

\footnotetext{
General rights rights.

- You may freely distribute the URL identifying the publication in the public portal. please follow below link for the End User Agreement:

www.umlib.nl/taverne-license

Take down policy

If you believe that this document breaches copyright please contact us at:

repository@maastrichtuniversity.nl

providing details and we will investigate your claim.
}

Copyright and moral rights for the publications made accessible in the public portal are retained by the authors and/or other copyright owners and it is a condition of accessing publications that users recognise and abide by the legal requirements associated with these

- Users may download and print one copy of any publication from the public portal for the purpose of private study or research.

- You may not further distribute the material or use it for any profit-making activity or commercial gain

If the publication is distributed under the terms of Article $25 \mathrm{fa}$ of the Dutch Copyright Act, indicated by the "Taverne" license above, 
Dr. Anouk H.H. Bollen-Vandenboorn

Faculteit der Rechtsgeleerdheid

\section{Grensoverschrijdende fiscale organisatie van pensioen}




\section{Grensoverschrijdende fiscale organisatie van pensioen}




\section{Colofon}

Design \& print: Canon Business Services, Maastricht

ISBN: 9789056814700

NUR: 826

All rights reserved. No part of this publication may be reproduced, modified, stored in a retrieval system or made public without the prior written permission of the author or publisher. 


\section{Grensoverschrijdende fiscale organisatie van pensioen}

\section{Rede}

Uitgesproken bij de aanvaarding van het ambt van bijzonder hoogleraar Grensoverschrijdend Fiscaal Pensioenrecht aan de Faculteit der Rechtsgeleerdheid van de Universiteit Maastricht

Maastricht, 16 december 2016

\section{Door}

Dr. Anouk H.H. Bollen-Vandenboorn 
The Institute for Transnational and Euregional cross border cooperation and Mobility (ITEM) is the pivot of scientific research, counselling, knowledge exchange, and training activities with regards to crossborder cooperation and mobility.

ITEM is an initiative of Maastricht University (UM), the Dutch Centre of Expertise on Demographic Changes (NEIMED), Zuyd University of Applied Sciences, the City of Maastricht, the Euregio Meuse-Rhine (EMR), and the Dutch Province of Limburg

Het Institute for Transnational and Euregional cross border cooperation and Mobility / ITEM is de spil van wetenschappelijk onderzoek, advisering, kennisuitwisseling en opleidingsactiviteiten omtrent grensoverschrijdende samenwerking en mobiliteit.

ITEM is een initiatief van Universiteit Maastricht (UM), het Nederlands Expertise en Innovatiecentrum Maatschappelijke Effecten Demografische krimp (NEIMED), Zuyd Hogeschool, de Gemeente Maastricht, de Euregio Maas-Rijn (EMR) en de Provincie Limburg (NL).
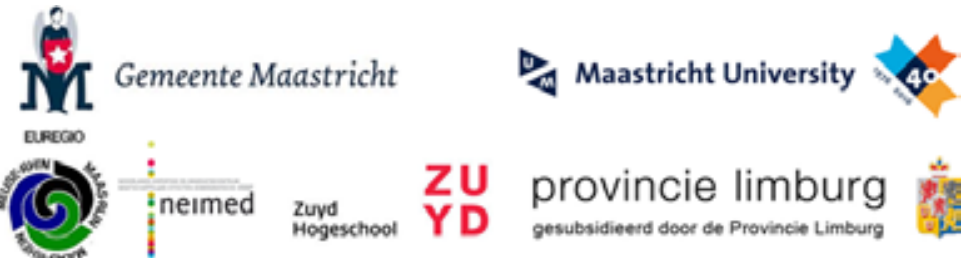
Opgedragen aan Raoul en Robin 
Mevrouw de Rector Magnificus, zeer gewaardeerde toehoorders,

\section{Aanleiding en inleiding}

Het is vandaag voor mij een bijzondere dag om hier op deze plaats te staan en mijn visie op pensioen met $u$ te mogen delen. In de komende drie kwartier wil ik u graag deelgenoot maken op welke wijze ik mijn bijdrage wil leveren aan het onderwijs, het wetenschappelijk onderzoek en het valoriseren van mijn pensioenkennis. Ik zal $u$ meenemen in het mooie pensioenlandschap en met $u$ de grenzen ervan verkennen. Ik laat $u$ zien op welke wijze grensoverschrijdend gewerkt kan worden en ook waar het grensoverschrijdend zou moeten werken. Dit laatste vraagt om organisatie. Organisatie vanuit een wetenschappelijke en beleidsmatige benadering, maar ook organisatie met het oog op vertaling naar praktijkgerichte toepassingen.

Toen ik op 1 januari 1996 als docent Belastingrecht in dienst kwam bij de capaciteitsgroep Belastingrecht van de toenmalige Rijksuniversiteit Limburg had ik nog geen idee hoe het pensioenvak mij zou gaan fascineren. Meteen al in het eerste jaar ging ik mij verdiepen in de pensioenmaterie aangezien Prof. mr. dr. René Niessen, destijds mijn leidinggevende en later mijn promotor, mij de opdracht gaf om aan de hand van twee A-viertjes twee onderwijsblokken op te zetten die onderdeel zouden uitmaken van de specialisatierichting 'Pensioen en Beleggen' van de doctorale opleiding Fiscaal Recht. Het ene blok was 'Lijfrente en levensverzekeringen' en het andere het blok 'Pensioen'.

Vol overgave heb ik mij gestort op deze materie en snel breidde de werkzaamheden zich van het onderwijsterrein uit naar het onderzoeksterrein en gingen mijn eerste publicaties al over pensioenen en andere oudedagsvoorzieningen. ' Wat al snel duidelijk werd is dat het pensioendomein vele facetten kent en bij uitstek interdisciplinair van aard is. Zo bleek dat ook tijdens mijn promotieonderzoek waarbij ik mij verdiept heb in de civiele en fiscale consequenties van pensioendeling bij echtscheiding. ${ }^{2}$

1 Mijn eerste publicatie, samen met Prof. dr. R.E.C.M. Niessen, in 1996 zag al op de oudedagsvoorzieningen, R.E.C.M. Niessen, A.H.H. Vandenboorn, Europees recht en fiscale begeleiding van oudedagsvoorzieningen, Stichting \& Vereniging, september/oktober 1996, nr. 5, blz. $143-148$.

2 A.H.H. Bollen-Vandenboorn, De fiscale aspecten van pensioendeling bij echtscheiding (dissertatie), 1 december 2004, blz. 1-392; verschenen als handelseditie A.H.H. Bollen-Vandenboorn, De fiscale aspecten van pensioendeling bij echtscheiding, Fiscaal Wetenschappelijke Reeks, Sdu Fiscale \& Financiële Uitgevers, Amersfoort, 2004, blz.1-390. 
Kenmerkend voor mijn promotieonderzoek was het werken vanuit het onderwerp, waardoor het niet anders kon dan voor een interdisciplinaire benadering te kiezen. Deze interdisciplinaire, en in zoverre grensoverschrijdende aanpak binnen een nationale context, ben ik blijven doen bij alle volgende stappen die ik binnen het pensioendomein heb gemaakt. De internationale, Europese en grensoverschrijdende fiscale aspecten zijn in de loop der tijd een steeds grotere rol gaan spelen, waardoor deze ook op een natuurlijke wijze verweven raakten in het onderwijs en onderzoek en daar niet meer uit weg te denken zijn.

Naasthetverbindenvanonderwijsen onderzoek, hechtikookgrotewaarde aan grensoverschrijdende en interdisciplinaire samenwerkingsvormen met de pensioenpraktijken andere wetenschappelijke kennisinstellingen. Op deze manier probeer ik de brug te maken tussen de wetenschap en de pensioenpraktijk. Om de cirkel vervolgens rond te maken, betrek ik via het onderwijs de studenten in deze samenwerkingsverbanden en grensoverschrijdende pensioenprojecten.

Dit doe ik door daadwerkelijk het pensioenspeelveld met hen op te zoeken. Zo laat ik hen vanuit het onderwijs participeren in het jaarlijkse Maasdalseminar, maar biedt hen ook de mogelijkheid om mee te gaan op de jaarlijkse internationale pensioenstudiereis.

Het genoemde Maasdalseminar komt voort uit het Maasdalsoverleg, een samenwerkingsverband tussen ABP/APG, AZL, DSM Pension Services en Universiteit Maastricht, dat we in 2005 hebben vormgegeven met als doelstelling kennis te delen en van elkaar te leren. ${ }^{3}$ Een andere samenwerking met de praktijk komt naar voren in het jaarlijkse Pensioenseminar. ${ }^{4}$ Dit pensioenseminar is bij uitstek interdisciplinair, brengt pensioenprofessionals en wetenschap bij elkaar en benadert actuele thematiek vanuit de vele pensioenperspectieven die er zijn; van fiscaliteit tot gezondheid, van risk management tot flexicurity en van governance tot de pensioenschijf van vijf.

3 Overige leden van Maasdaloverleg: Mr. Leo Bessems (APG), Drs. Cyril Savelkoul (APG), Mr. Kerstin Thoma (APG), Ir. Gerard Rutten (DPS / bestuurslid Pensioenfederatie), Jos Maarschalkerweerd (AZL), Dr. Marjon Weerepas (UM).

4 Raad van Advies Pensioenseminar: Ir. Gerard Rutten (DPS / bestuurslid Pensioenfederatie), Dr. Ruud Kleynen AG (Kleynen Consultants), Prof. dr. Roland Brandsma (PwC, UvA, Nyenrode Business University, Radbouduniversiteit Nijmegen), Ir. Lilian van Duijnhoven AG (PWC). 
Door op deze wijze te werken en pensioenkennis te delen, creëer je synergievoordelen voor een ieder en kom je tot het optimaal valoriseren van kennis binnen de samenleving. Aan dit alles ligt wetenschappelijk onderzoek en debat ten grondslag. Vanuit ITEM ${ }^{5}$ en het Maastricht Centre for Taxation ${ }^{6}$ zal ik ook door samenwerking met andere kennisinstellingen en universiteiten in binnen- en buitenland werken aan de verbetering van grensoverschrijdend fiscaal pensioenverkeer.

Zoals net aangegeven wordt er jaarlijks letterlijk uitvoering gegeven aan grensoverschrijdend fiscaal pensioenverkeer. Op initiatief van Prof. dr. Gerry Dietvorst, waarmee ik al vele jaren samenwerk, wordt sinds 2007 de International Study trip on Pensions georganiseerd. Tilburgse en Maastrichtse studenten verbreden en verdiepen zo hun grensoverschrijdende pensioenkennis door het Nederlandse pensioenstelsel ter plaatse te vergelijken met het pensioenstelsel van het betreffende land.7 Onder andere door dit soort rechtsvergelijkende studies en discussies wordt steeds weer bevestigd dat er nog grote verschillen bestaan tussen de pensioenstelsels van alle landen en de fiscale regels die daarop van toepassing zijn.

\section{Grensoverschrijdende fiscale organisatie van pensioen}

Wanneer het grensoverschrijdende pensioendomein voor de professional nog een groot terrein is met vele onduidelijkheden en ontbrekende aansluitingen, is het probleem voor de mobiele werknemer en de gepensioneerde met grensoverschrijdend pensioenverkeer des te groter om daar inzicht in te krijgen.

Dit onderstreept het belang om te komen tot een grensoverschrijdende persoonlijke informatievoorziening over pensioenen, waarin iedereen kan zien hoeveel pensioen hij gaat ontvangen zodra hij stopt met werken.

5 ITEM, the Institute for Transnational and Euregional cross border cooperation and Mobility, www.maastrichtuniversity.nl/item

6 MCT, www.maastrichtuniversity.nl/taxation.

7 ISoP-reizen: Budapest - Hongarije (2007), Porto - Portugal (2008), Lodz - Polen (2010), Wenen Oostenrijk (2012), Luxemburg - Luxemburg (2013), Osnabrück - Duitsland (2014), Kopenhagen - Denemarken (2015), Stockholm - Zweden (2016). 
Voordat echter naar de vraag gekeken kan worden wat een gepensioneerde aan pensioen gaat ontvangen uit binnen- en buitenland, zal eerst duidelijk moeten zijn wat onder pensioen begrepen wordt, of er pensioen is opgebouwd en waar. Hoewel in veel landen pensioen kan worden opgebouwd, zijn deze pensioenen niet zonder meer vergelijkbaar met elkaar. leder land heeft zijn eigen pensioenstelsel met eigen uitgangspunten.

Bovendien zijn de verhoudingen tussen en de voorwaarden met betrekking tot wettelijke pensioenen uit de eerste pijler, het werknemerspensioen uit de tweede pijler en de individueel geregelde pensioenvoorzieningen uit de derde pijler, afwijkend.

In ieder land is de betrokkenheid van de publieke en private sector anders geregeld. Ook zien we grote verschillen in de keuze om de pensioenvoorziening te financieren op omslagbasis of kapitaaldekking. En dan spreek ik nog niet over de vorm waarin de pensioenopbouw gegoten wordt; dat kan een defined benefit-regeling zijn, een defined contribution-regeling, een regeling op basis van pensioenpunten, een notional pension account of een notional defined contribution-regeling. De systemen die ik hier benoem betreffen enkel de hoofdvormen en zeggen niets over de mogelijke mengvormen of details van afzonderlijke regelingen.

Vervolgens heeft ieder land zijn eigen fiscale wet- en regelgeving waarin bepaald wordt op welke wijze de opbouw van pensioen al dan niet gefaciliteerd wordt en in hoeverre de pensioenuitkeringen in de belastingheffing worden betrokken.

De grote verschillen in de pensioenstelsels en -systemen alsmede de vasthoudendheid aan de fiscale autonomie van een land laten het niet toe dat pensioen op Europees niveau geharmoniseerd wordt. ${ }^{8}$ Dit neemt niet weg dat op andere wijze eraan gewerkt kan worden om grensoverschrijdend verkeer te bevorderen met respect voor de pensioenstelsels in een land. Dit vergt echter een andere aanpak.

8 Op grond van art. 115 Verdrag betreffende de werking van de Europese Unie (VWEU) is EUbelastingwetgeving alleen mogelijk wanneer deze met unanimiteit wordt aangenomen. 
Zo heeft bijvoorbeeld het Rustpensioen in België, de Rentenversicherung in Duitsland, de Cotisations Pension in Luxemburg en de AOW en het werknemerspensioen in Nederland dezelfde doelstelling en ook een aantal gemeenschappelijke kenmerken, maar ook de nodige verschillen. Het ontbreken van de aansluitingen kan afhankelijk van de individuele situatie leiden tot het niet verzekerd zijn voor de oudedagsvoorziening, tekorten in de aanvullende pensioenopbouw, het niet verkrijgen van fiscale faciliteiten, dubbele belastingheffing of juist helemaal geen heffing.

Dit wil overigens niet zeggen dat er geen afspraken bestaan, maar er bestaat geen uniforme fiscale aanpak hoe om te gaan met deze grensoverschrijdende en internationale pensioensituaties.

Vanuit Europese verordeningen en richtlijnen kan ten aanzien van de fiscaliteit niets voorgeschreven worden. Wel kunnen andere middelen ingezet worden om sturing te geven. De Europese Commissie is daar terughoudend in. Zo zien we bijvoorbeeld maar één Mededeling uit 2001 waarin aandacht gevraagd wordt voor het opheffen van de fiscale barrières voor grensoverschrijdende deelneming aan pensioen regelingen alsook voor grensoverschrijdende overdracht van pensioenrechten. ${ }^{9}$ Deze Mededeling leidde weliswaar tot de inwerkingtreding van de Mobiliteitsrichtlijn in 2014, maar enige fiscale sturing is daarin niet meegenomen. ${ }^{10}$ In 2012 wordt in het Witboek Pensioen door de Europese Commissie opnieuw aangegeven waarde te hechten aan het verminderen van fiscale obstakels voor grensoverschrijdende mobiliteit en grensoverschrijdende investeringen." De Europese Commissie heeft echter weinig bewegingsruimte.

9 Mededeling van de Commissie aan de Raad, het Europees Parlement en het Economisch en Sociaal Comité, De opheffing van fiscale barrières voor grensoverschrijdende bedrijfspensioenregelingen, $\mathrm{COM} / 2001 / 0214$ def.

10 Richtlijn 2014/50/EU van het Europees Parlement en de Raad van 16 april 2014 betreffende minimumvereisten voor de vergroting van de mobiliteit van werknemers tussen de lidstaten door het verbeteren van de verwerving en het behoud van aanvullende pensioenrechten (Mobiliteitsrichtlijn).

11 Witboek, Een agenda voor adequate, veilige en duurzame pensioenen, Brussel 16.02.2012, $\operatorname{COM}(2012) 55$ finl 
De meeste sturing die op dit moment vanuit Europese context gegeven wordt is afkomstig van het Europese Hof van Justitie. Ofwel door het stellen van prejudiciële vragen door nationale rechters ofwel door inbreukprocedures die gestart worden door de Europese Commissie tegen lidstaten. Op deze wijze kan enige afbakening gemaakt worden en enige sturing gegeven worden.

Ook op het internationale vlak is er geen overkoepelende organisatie die kan beslissen of sturen hoe de fiscaliteit rondom pensioen en de onderliggende pensioenregelingen eruit moet zien.

In het OESO-modelverdrag is bijvoorbeeld wel opgenomen hoe verdragslanden kunnen omgaan met de heffingsbevoegdheid rondom pensioen ${ }^{12}$, maar in het bijbehorende commentaar wordt er op gewezen dat de fiscale stelsels per land kunnen verschillen en ook dat er verschillende opvattingen bestaan ten aanzien van de rol van sociale zekerheidsuitkeringen. ${ }^{13}$ Zoals de naam van het verdrag al aangeeft, gaat het hier om een modelverdrag waaruit alleen tot op zekere hoogte enige afstemming is af te leiden. Verdragslanden zullen altijd samen moeten kijken naar elkaars pensioenstelsel en bijbehorend fiscaal regime alvorens afspraken te maken over grensoverschrijdend pensioen. Aangezien fiscale afspraken ter voorkoming van dubbele belasting worden opgenomen in een bilateraal verdrag tussen twee landen bestaat er zonder meer de ruimte om af te wijken van de hoofdregels zoals opgenomen in het OESO-Modelverdrag. Kijken we naar Nederland dan zien we dat Nederland ervoor gekozen heeft haar verdragsbeleid op te nemen in een aparte notitie, zodat het voor een ieder in binnen- en buitenland helder is wat de Nederlandse uitgangspunten zijn. ${ }^{14}$

Er blijkt dus met betrekking tot grensoverschrijdend fiscaal pensioen geen officiële weg van harmonisatie of coördinatie te zijn. Dat betekent dat het grensoverschrijdend fiscaal pensioenverkeer op andere wijze zo optimaal mogelijk georganiseerd moet worden. Hierin ligt voor mij in de komende jaren de uitdaging.

\footnotetext{
12 Zie artikel 18 en 19, lid 2 OESO Modelverdrag.

13 Commentary on article 18 concerning the taxation of pensions, and Commentary on article 19 concerning the taxation of remuneration in respect of government service, Model Tax Convention

14 Ministerie van Financiën, Notitie Nederlands Fiscaal Verdragsbeleid, 11 februari 2011.
} 
Twee dimensies van 'Grensoverschrijdend'

In mijn optiek kent het begrip 'grensoverschrijdend' twee dimensies. Enerzijds ziet dat op de grensoverschrijdende fiscale organisatie van pensioen binnen een nationale context en anderzijds ziet dat op de grensoverschrijdende fiscale organisatie van pensioen binnen een transnationale en internationale context.

Als we kijken naar het grensoverschrijdend pensioen binnen een nationale context gaat het erom het pensioen in een breder perspectief te plaatsen. Een harde grens tussen de arbeidsfase en de pensioenfase bestaat niet meer. De grens tussen deze fases is aan het vertroebelen, doordat enerzijds de arbeidsfase niet meer voor iedereen op hetzelfde moment stopt en anderzijds de pensioenfase ook niet voor iedereen op hetzelfde moment begint. Bovendien is de gemiddelde uittreedleeftijd in Nederland nog altijd lager dan de gemiddelde pensioenleeftijd. Als complicerende factor komt er dan nog bij dat voor de AOW een andere leeftijd wordt aangehouden als voor het werknemerspensioen.

De Nederlandse arbeidsmarkt is sterk aan het veranderen. Het traditionele loopbaanmodel van een leven lang werken bij één werkgever bestaat niet meer. Er wordt steeds vaker gewisseld van werkgever, waarbij ook steeds meer gewerkt wordt op basis van tijdelijke contracten. Bovendien wordt het werk steeds meer in verschillende arbeidsvormen gedaan. De groep van zelfstandigen zonder personeel (zzp-ers) en flexwerkers wordt steeds groter. $66 \%$ van de beroepsbevolking is nog in dienstbetrekking met een vast contract. De resterende $34 \%$ van de beroepsbevolking behoort tot de zojuist genoemde flexibele schil.15

Daarbij moet opgemerkt worden dat bij wijzigingen in het arbeidspatroon van een werkende hij zijn arbeidsvorm niet altijd één op één aanpast. Vaak wordt ook voor een combinatie gekozen van deeltijdwerk in dienstbetrekking en de resterende tijd bijvoorbeeld als zzp-er. Een werknemer kan er ook voor kiezen zijn activiteiten voort te zetten als ondernemer of vanuit zijn eigen BV waarbij hij zelf directeurgrootaandeelhouder is. Niet in alle gevallen is sprake van een vrijwillige keuze. Mensen die bijvoorbeeld door ontslag getroffen zijn, worden door de omstandigheden gedwongen in andere arbeidsvormen te gaan werken.

15 Zie http://statline.cbs.nl/statweb/publication/?vw $=$ t\&dm $=\sin \mid \& p a=82309$ ned \&d1=0,2$10,22 \& d_{2}=0 \& d_{3}=0 \& d_{4}=0 \& d_{5}=(\mid-13)-I \& h d=151216-1202 \& h d r=g 1, g 2, g 3, t \& s t b=g 4$. 
Voor alle situaties geldt dat door middel van arbeid het inkomen verdiend moet worden. Inherent daaraan is dat er ook gezorgd moet worden voor inkomen voor de postactieve fase oftewel de pensioenfase.

Wanneer in verschillende arbeidsvormen gewerkt wordt, ontstaan er ook verschillende soorten van 'pensioenpotjes' met eigen kenmerken en voorwaarden. Genoemd kunnen worden het al dan niet verplicht gestelde bedrijfstakpensioen, het ondernemerspensioen, het verplicht gestelde beroepspensioen, de fiscale oudedagsreserve, de lijfrente, een lijfrentespaarrekening, een lijfrentebeleggingsrecht, de stakingswinstlijfrente, het eigen beheerpensioen en vanaf 1 januari de oudedagsverplichting.

Los van de civielrechtelijke contouren en voorwaarden zijn aan deze pensioenvormen verschillende fiscale regels verbonden.

Opvallend daarbij is dat de fiscale facilitering van de diverse pensioenvormen niet gelijk zijn in de opbouwfase. Dat past niet meer in de huidige tijd. Op het moment dat iemand stopt met werken wil hij kunnen genieten van zijn pensioen. In zoverre verkeert iedereen vanaf pensioendatum onder gelijke omstandigheden en is niet meer relevant de wijze waarop iemand zijn inkomen heeft verdiend. ledereen wil kunnen beschikken over een maandelijks bedrag om in zijn levensonderhoud te kunnen voorzien en moet daarvoor mijns inziens dezelfde fiscale ruimte krijgen om dat op te bouwen.

Hoewel de fiscale wetgever stelt dat wetgeving eenvoudig toepasbaar moet zijn en niet complex, gaat dat echter niet op voor een werkende persoon in Nederland die door de diverse opgebouwde pensioenpotjes met verschillende fiscale regelgeving geconfronteerd wordt. Dit vraagt om een fiscale bijstelling van wetgeving.

Kijken we naar de doelstelling van de Europese Commissie dan is deze er ook op gericht adequate pensioeninkomens te verschaffen en ouderen in staat te stellen een fatsoenlijke levensstandaard en economische onafhankelijkheid te genieten. Om maximale steun te bieden, beveelt de Europese Commissie de verdere ontwikkeling van aanvullende pensioenregelingen aan en moedigt zij aan om tot een optimale balans tussen eerste, tweede en derde pijler te komen. ${ }^{16}$ 
Ook de Staatssecretaris van Sociale Zaken en Werkgelegenheid geeft in de 'Perspectiefnota Toekomst Pensioenstelsel' de noodzaak tot aanpassing van het pensioenstelsel aan vanwege de veranderingen in de samenleving. ${ }^{17}$ De staatssecretaris geeft aan naar de juridische en fiscale kaders te kijken zodra er een nadere invulling is van de pensioenovereenkomsten.

Naar mijn mening dient dit vanuit de fisca liteit breed opgepakt te worden. Dus niet alleen maar aanpassing van fiscale wetgeving vanwege andere pensioenovereenkomsten, maar aanpassing van fiscale wetgeving passend bij de gehele veranderende arbeidsmarkt en bijbehorende pensioenvoorzieningen. Gelet op het bovenstaande biedt een fiscaal arbeidsvormneutraal pensioenkader hierin een uitweg. ${ }^{18}$ Binnen dit kader krijgt iedere werkende persoon evenveel fiscale ruimte om zijn pensioen te kunnen opbouwen ongeacht zijn arbeidsvorm. Een dergelijk systeem sluit aan bij de veranderende en flexibele arbeidsmarkt waarin we ons bevinden.

Inmiddels wordt in Nederland de norm gehanteerd dat van een adequaat pensioen gesproken mag worden als dit pensioen $75 \%$ bedraagt van het gemiddelde loon dat in 40 jaar tijd wordt opgebouwd. Uitgaande van deze norm zouden alle pensioenopbouwmogelijkheden fiscaal zo ingericht moeten worden dat ze op elkaar afgestemd zijn en aansluiten. Of een werknemer nu gedurende zijn hele loopbaan pensioen kan opbouwen via één werkgever of dat iemand zijn werkzaamheden doet vanuit zijn parttime dienstbetrekking in combinatie met zzp-activiteiten en vervolgens DGA wordt. In beide gevallen zouden ze dezelfde fiscale ruimte moeten hebben om pensioen op te bouwen.

Hierbij zien we dat de fiscale grens tussen de tweede en derde pijler in Nederland een beetje begint te vervagen, aangezien bij de lijfrentepremieaftrekberekening al rekening wordt gehouden met de norm van $75 \%$ van het gemiddeld loon. Ook zien we dat de pensioenleeftijden op elkaar worden afgestemd als ook de inbouw van de aftoppingsgrens van ruim $€ 100.000$ (101.519 in 2016).

17 Ministerie van Sociale Zaken en Werkgelegenheid, Perspectiefnota Toekomst pensioenstelsel, 8 juli 2016

18 Werkgroep Arbeidsvormneutraal pensioenkader, Arbeidsvormneutraal pensioenkader: een logische vervolgstap, Competence Centre for Pension Research, Fiscaal Instituut Tilburg, Tilburg University, 2013. 
Toch zijn we er nog niet want vele andere elementen in de betreffende fiscale bepalingen zijn afwijkend en wel zodanig dat als de berekening gemaakt wordt aan de hand van één inkomensbedrag, hier verschillende uitkomsten uit voortkomen. Nu echter de bewustwording in Nederland is ontstaan dat bij pensioenopbouw rekening gehouden moet worden met de verschillende arbeidsvormen, pleit ik er wel voor om dan ook meteen naar de fiscale begeleiding te kijken en deze kans niet te laten liggen.

Hier kan zelfs nog een stapje verder gezet worden door ook binnen Europa te pleiten voor een soortgelijk fiscaal systeem, zeker nu vanuit de Europese Commissie ook gewezen wordt op het belang van het regelen van aanvullende individuele pensioenen zodat een evenwichtiger verdeling ontstaat over de drie pijlers. Prof. dr. Gerry Dietvorst sprak in dit verband al over de 'compensating layers' of de 'compensating vessels', hetgeen ook terugkwam in het Groenboek Pensioen. ${ }^{19}$

De verhoudingen tussen de eerste, tweede en derde pensioenpijler in Europa zijn namelijk behoorlijk verschillend. Nederland en Denemarken springen Europees gezien er in positieve zin bovenuit doordat zij een sterke en evenwichtige verdeling hebben in met name de eerste en tweede pijler. Als we bijvoorbeeld naar de verdeling in het pensioenstelsel van Nederland kijken zien we dat dit voor 54\% uit de eerste pijler bestaat met de AOW. Voor $40 \%$ uit de tweede pijler met het werknemerspensioen en vervolgens nog $6 \%$ met individuele lijfrentevoorzieningen en soortgelijke bankspaarproducten. ${ }^{20}$ In andere landen is het pensioenstelsel met name gebaseerd op de wettelijke pensioenen uit de eerste pijler en is er niet zo'n grote tweede pijler aanwezig. De druk in het kader van financierbaarheid en houdbaarheid van het pensioenstelsel is in die landen behoorlijk groot, waarbij een aanvulling daarop met pensioenvoorzieningen in de derde pijler des te wenselijker is.

\footnotetext{
19 Groenboek Naar adequate, houdbare en zekere Europese pensioenstelsels, $\operatorname{COM}(2010) 365$ definitief

20 C. Schmitz, F. Barb, A. Bruil, CBS Discussion Paper, Constructing the Supplementary Pension Table for the Netherlands, 2015/7, figure 15 .
} 
Op dit moment wordt binnen Europees verband gekeken naar de mogelijkheden om te komen tot een EU framework voor Persoonlijke Pensioenproducten. ${ }^{21}$ Het idee van het fiscale systeem met de compensating layers past daar heel goed binnen.

De veranderende arbeidsmarkt is één van de elementen die dwingen na te denken over de opbouw en vormgeving van pensioen. Een ander element betreft de toenemende levensverwachting. De wetgever heeft hier al rekening mee gehouden door de AOW-leeftijd te verhogen en ook de pensioenrichtleeftijd voor de aanvullende pensioenen. Helaas lopen de aanpassingen van deze leeftijden niet meer synchroon en dat zal in de toekomst ook niet meer gaan gebeuren, tenzij door toevallige samenloop.

De AOW-leeftijd loopt in de komende jaren op tot 67 jaar en 3 maanden in 2022. Overigens vindt een jaarlijkse toetsing plaats, waardoor de kans zeer aannemelijk is dat deze leeftijd nog wel eens verhoogd zal worden. Hetzelfde zien we voor de pensioenrichtleeftijd in de aanvullende pensioenen. Deze is op dit moment 67 jaar, maar zal per 1 januari 2018 op 68 jaar gesteld worden. Ook deze pensioenrichtleeftijd wordt jaarlijks getoetst. Wanneer uit de berekening blijkt dat de levensverwachting met een vol jaar is gestegen zal dit ook leiden tot een verhoging van de pensioenrichtleeftijd met een jaar.

Wat hierbij natuurlijk opvalt, is dat de AOW-leeftijd en de pensioenrichtleeftijd uit de pas lopen. De wetgever heeft de koppeling van beide voorzieningen helaas losgelaten, hetgeen betekent dat te allen tijde afstemming en aanpassing zal moeten plaatsvinden tussen het wettelijk pensioen en het aanvullend pensioen. In dit verband juich ik het wetsvoorstel flexibilisering AOW-leeftijd toe. ${ }^{22}$ Dit biedt de burger de mogelijkheid om de oudedagsvoorzieningen, waaronder ook de buitenlandse, op elkaar af te stemmen met inachtneming van zijn persoonlijke omstandigheden. Met name dit laatste punt is van groot belang. We zijn immers geen 'maatmannen' maar mensen van vlees en bloed.

21 EIOPA, Towards an EU-single market for personal pensions, An EIOPA Preliminary Report to COM, EIOPA-BoS-14/O29, eiopa.europe.eu.; zie ook European Commission, Consultation document, Capital Markets Union: Action on a potential EU Personal Pension Framework, http:// ec.europa.eu/finance/consultations/2016/personal-pension-framework/docs/consultationdocument en.pdf

22 Wet flexibilisering ingangsdatum AOW, TK 2015-2016, 34414. 
Een maatregel als het verhogen van de AOW-leeftijd en de pensioenrichtleeftijd werkt prima als iedereen ook daadwerkelijk doorwerkt tot de genoemde leeftijd. Realiteit is echter anders. De gemiddelde uittreedleeftijd van een werknemer in 2015 was volgens het CBS 64,4 jaar. In 2000 was dat nog 60,8 jaar. ${ }^{23,24}$ Wat in ieder geval geconcludeerd kan worden is dat er een stijgende lijn inzit, maar ook dat de genoemde leeftijden nog altijd niet gelijk zijn aan de AOW-en pensioenrichtleeftijd. Laat staan dat de leeftijden in de buurt komen van de bijgestelde toekomstige AOW- en pensioenrichtleeftijd.

Reden voor die kloof is heel divers. Behalve een vrijwillige keuze om eerder het arbeidsproces te verlaten, worden de meeste mensen door de omstandigheden gedwongen eerder te stoppen met werken. Denk hierbij aan mensen met gezondheidsproblemen, mensen met zwaar fysiek werk, maar ook mensen die vanwege boventalligheid door ontslag het arbeidsproces moeten verlaten.

We moeten dus constateren dat een harde grens tussen arbeidsfase en pensioenfase niet bestaat. Door de ontwikkelingen en de wettelijke aanpassingen ontstaat er een steeds ruimere transitiefase tussen de arbeidsfase en de pensioenfase. De vraag die dit oproept is hoe de werkende en de arbeidsmarkt gestimuleerd kunnen worden om die transitiefase zo optimaal en adequaat te laten verlopen en welke rol de fiscaliteit daarin kan spelen.

Optimaal en adequaat in die zin dat enerzijds degene die niet meer kan werken de mogelijkheid moet hebben om de arbeidsfase al dan niet deels te verlaten met behoud van een adequaat inkomen, terwijl de werkende die tot de pensioenleeftijd kan werken hiertoe ook gestimuleerd moet worden.

$\mathrm{Nu}$ de arbeidsmarkt zo flexibel en divers is geworden, betekent dit dat een maatregel die hierin kan faciliteren niet uitsluitend moet zien op de werknemer, maar op de werkende. Arbeidsvormneutraliteit is een nieuwe kernwaarde die in acht genomen moet worden bij het ontwikkelen van beleid en het treffen van maatregelen.

$23 \mathrm{http}: / /$ statline.cbs.nl/Statweb/publication/?VW $=T \& D M=S L N L \& P A=80396$ ned \&D $1=1,9 \& D 2=0$ $\& D 3=0 \& D 4=0 \& D 5=0-2 \& D 6=0-1,3-6,9-12,14,17-20 \& D 7=0 \& D 8=0,6-7,12-15 \& H D=161105-$ $1727 \& H D R=T, G 7 \& S T B=G_{1}, G_{2}, G_{3}, G_{4}, G_{5}, G_{6}$.

24 In het OECD rapport lag de effectieve uittreedleeftijd lagen, namelijk 62,9 jaar voor mannen en 61,9 jaar voor vrouwen, OECD, Pensions at a Glance 2015, OECD and G20 indicators, p. 163, table 7.8, Statlink http://dx.doi.org/10.1787/888933300814. 
Voornoemde aspecten komen ook aan bod in het promotieonderzoek van Elianne Janssen waarbij wij willen komen tot een fiscale maatregel die de transitieperiode van arbeidsfase naar pensioenfase zo optimaal mogelijk faciliteert.

Grensoverschrijdende fiscale organisatie binnen transnationale context Hoe plaatsen en vertalen we deze ontwikkelingen in een transnationale context? Het moge duidelijk zijn dat menige burger in Nederland een versnipperde opbouw van pensioen heeft. Voor de jaren dat hij in Nederland ingezetene was, heeft hij AOW-rechten opgebouwd. Daarnaast zal hij stukjes pensioen hebben opgebouwd bij de diverse werkgevers waarvoor hij gewerkt heeft. Soms kiest een werknemer ervoor waardeoverdracht van het pensioen te laten plaatsvinden, maar veelal laat hij het staan bij zijn oude werkgever.

\section{Grensoverschrijdend pensioenregister}

Wanneer een burger een overzicht wil hebben van wat hij aan pensioen heeft opgebouwd, kan hij dat doen door alle Uniforme Pensioenoverzichten (UPO's) te verzamelen. Daarbij gelden voor pensioenuitvoerders verschillende verplichtingen met betrekking tot het moment waarop deze persoonlijke pensioeninformatie verstuurd wordt, nu hun bestand niet alleen uit actieve deelnemers bestaat, maar ook uit de gewezen deelnemers en slapers. Met de komst van het pensioenregister in 2011 is de pensioeninformatievoorziening in Nederland verbeterd. ${ }^{25}$ Sinds die tijd kan iedere burger met een DigiD op www.mijnpensioenoverzicht.nl zien hoeveel pensioen hij in totaal heeft opgebouwd en bij wie.

Degene met veel kleine pensioenen heeft zo een totaal overzicht, maar ook degene die in het verleden bijvoorbeeld pensioen heeft opgebouwd via een werkgever en die daarna als zzp-er of ondernemer is gaan werken behoudt het overzicht.

$\mathrm{Nu}$ is Nederland een land met 12 provincies, waarvan 7 grensprovincies. Ook weten we dat er in en vanuit Nederland veel over de grens gewerkt wordt. De mobiele werkende kan daarbij vele hoedanigheden hebben, van grensarbeider tot gedetacheerde werknemer. Deze grensoverschrijdende mobiliteit doet zich natuurlijk niet alleen voor in en vanuit Nederland, maar in heel Europa.

25 Wet van 27 januari 2011 tot wijziging van de Pensioenwet en de Wet verplichte beroepspensioenregeling in verband met de inrichting en het beheer van het pensioenregister, Stb. 2011, 26. 
In 2014 woonden in Europa alleen al 8,3 miljoen economisch actieve burgers in een andere lidstaat dan hun oorspronkelijke woonstaat. ${ }^{26}$ En dan spreek ik alleen over Europese burgers die zich binnen Europa verplaatsen en nog niet over derdelanders die in Europa economisch actief zijn. Dit betekent dat er veel mobiele werknemers zijn die in verschillende landen pensioen opbouwen. Als het al wenselijk is om binnen een land een goede pensioeninformatievoorziening te hebben, is het van nog grotere toegevoegde waarde om een goed grensoverschrijdend pensioeninformatiesysteem te hebben dat inzicht geeft in de in diverse landen opgebouwde pensioenen.

Met een dergelijk systeem wordt de noodzaak om internationale waardeoverdracht van pensioen te laten plaatsvinden overigens minder groot. De rechthebbende loopt immers niet meer het risico pensioenen te 'vergeten' aangezien alles bij elkaar staat. Voor landen, waaronder Nederland, die zich verzet hebben tegen het reguleren van internationale waardeoverdracht via de Mobiliteitsrichtlijn, is een Europees pensioenregister een goed alternatief.

Het toenemend aantal mobiele werkenden op de Europese arbeidsmarkt kan dus via dit Europees pensioenregister snel en accuraat inzicht krijgen in hun grensoverschrijdend opgebouwd pensioen. Een dergelijk systeem is een positieve impuls voor de arbeidsmobiliteit van werknemers. Het ontzorgt de burger.

De aanzet voor een Europees pensioenregister zien we al in het Groenboek Pensioen. De Europese Commissie geeft ook daarna in het Witboek Pensioen aan belang te hechten aan de ontwikkeling en totstandkoming van een dergelijke informatievoorziening. ${ }^{27}$ Dit heeft geleid tot het ontstaan van het TTYPE-consortium. Met TTYPE wordt bedoeld 'Track and Trace your pension in Europe'. Het idee van het TTYPE-consortium is om te komen tot éen groot European Tracking Service (ETS) waarin alle lidstaten participeren. Het consortium heeft de haalbaarheid van een dergelijke service getoetst. In hun eindrapport

26 Zie Labour Mobility Package, presentatie Labour Mobility in the EU: facts, figures and the labour mobility package, door European Commission - DG Employment, Social Affairs and Inclusion Free Movement of Workers and Coordination of Social Security Systems, 27 oktober 2015 .

27 Witboek, Een agenda voor adequate, veilige en duurzame pensioenen, $\operatorname{COM}(2012) 55$ final, par. 3.2. 
is opgenomen welke strategische implementatie-aanpak gevolgd zou moeten worden en het financiële model voor de houdbaarheid van het systeem. ${ }^{28}$ Op de details van een dergelijk systeem wordt niet ingegaan.

Ik maak mij graag sterk voor de totstandkoming van een dergelijk Europees pensioenregister, maar we moeten ook realistisch zijn. Op korte termijn is het niet mogelijk om een dergelijk systeem te realiseren. Reden daarvoor is ten eerste de te grote diversiteit aan pensioenstelsels in Europa met de daaraan gekoppelde wet- en regelgeving die van toepassing is. Daarnaast zijn er nog andere aandachtspunten zoals bijvoorbeeld de privacygevoeligheid van de data die niet zomaar grensoverschrijdend gedeeld kan worden, maar ook de vraag wie nu verantwoordelijk is voor het opzetten van een dergelijk systeem en wie het daadwerkelijk gaat financieren. Hoever gaan de overheden van de lidstaten en hoever gaan de non-profit pensioeninstellingen of de verzekeraars?

Het op korte termijn verbinden van alle systemen tot één functionerend Europees pensioenregister is mijn inziens op dit moment nog een brug te ver. Ik ben dan ook van mening dat een dergelijk systeem eerst op kleine schaal ontwikkeld moet worden. Om die reden heb ik ervoor gekozen een onderzoekslijn op te zetten om te komen tot een grensoverschrijdend pensioenregister met de landen Nederland, Duitsland en België.

In dit grensoverschrijdende pensioenregister moet het mogelijk zijn dat een burger op een duidelijke en overzichtelijke manier kan zien hoeveel en wanneer hij netto pensioen gaat ontvangen uit Duitsland, Nederland en België.

Dit klinkt eenvoudig maar vraagt de nodige fiscale vertalingen en verbindingen. Bovendien zijn er in alle drie de landen nog wel wat slagen te maken wanneer we inzicht willen krijgen met betrekking tot grensoverschrijdend pensioen.

In Duitsland moet eerst nog een nationaal pensioenregister tot stand komen waarin de Duitse pensioenen zijn opgenomen. In Nederland en België bestaat al zo'n nationaal pensioenregister, maar daarin is geen informatie te vinden over pensioen dat over de grens is opgebouwd.

28 Establishing an ETS, Business plan for a European Tracking Service, June 2016, http://ttype. eu/wp-content/uploads/TTYPE-Establishing-an-ETS-business-plan-for-a-European-TrackingService1.pdf. 
Dit soort belemmeringen dienen weggenomen te worden en zijn tevens ook aandachtspunten voor een Europees grensoverschrijdend pensioenregister.

Naast deze vragen zit er ook een behoorlijke portie grensoverschrijdende fiscaliteit in die voor de gebruiker van het pensioenregister niet zichtbaar is, maar waar de functionaliteit en de meerwaarde van een dergelijk systeem mee staat of valt.

Stel $u$ woont en werkt in Nederland. Hierdoor bouwt $u$ AOW-rechten op in Nederland en bij uw werkgever bouwt u uw werknemerspensioen op. Vervolgens wordt u door uw werkgever voor de duur van drie jaar gedetacheerd in Berlijn. Vanwege de afstand gaat $u$ ook in Duitsland wonen. Uw Nederlandse werkgever maakt afspraken met de werkgever waar u gedetacheerd bent over de voortzetting van de pensioenopbouw. Met betrekking tot de AOW kan de werkgever geen afspraken maken, daar bent u zelf verantwoordelijk voor. In Duitsland bestaat echter wel de Rentenversicherung, zijnde het wettelijke eerste pijlerpensioen zoals wij de AOW kennen. Na die drie jaar komt u terug naar Nederland en zet uw werkzaamheden voort bij de oorspronkelijke Nederlandse werkgever. Dit is echter van korte duur want $u$ neemt een nieuwe dienstbetrekking aan in Brussel en $u$ verhuist om aldaar te gaan wonen en werken. Als werknemer komt $u$ in aanmerking voor opbouw voor het Rustpensioen uit de eerste pijler en het eveneens wettelijk geregelde tweede pijler pensioen. Na een aantal jaren keert $u$ toch weer terug naar Nederland om van uw pensioen te genieten.

Dit voorbeeld is geen extreem voorbeeld, maar uit de dagelijkse praktijk gegrepen. $U$ komt in de situatie dat $u$ gaat nadenken over uw pensioen. Wat zou $u$ dan willen weten? Volgens mij wilt $u$ weten hoeveel netto te besteden pensioen $u$ in totaal heeft opgebouwd om aan de hand daarvan te kunnen vaststellen of $u$ daarmee in uw levensonderhoud kunt voorzien zodra u gepensioneerd bent Deze vraag dient achter de schermen in het systeem verwerkt te worden. De gebruiker dient alleen het resultaat gepresenteerd te krijgen. Veel facetten gaan dan een rol spelen. Daarbij is van belang in welke landen $u$ sociaal verzekerd bent geweest en of $u$ op basis daarvan pensioenrechten heeft opgebouwd. In Nederland bouwt $u$ vanaf de vastgestelde aanvangsleeftijd in beginsel $2 \%$ AOW-rechten op voor ieder jaar dat $u$ ingezetene bent geweest van Nederland. ${ }^{29} \mathrm{U}$ bouwt geen kapitaal op, enkel rechten.

29 Zie art. 7a Algemene Ouderdomswet. 
Duitsland kent een met de AOW vergelijkbare Rentenversicherung, maar bijzonder is dat pensioenrechten pas definitief toegekend worden wanneer de betrokkene ten minste vijf aaneengesloten jaren werkzaamheden in dienstbetrekking verricht. Nu u maar drie jaar in Duitsland woont en werkt, tellen deze jaren voor de Rentenversicherung dus niet mee en bouwt $u$ niets op terwijl $u$ wel premies betaald heeft. In Nederland bent $u$ geen ingezetene en dus bouwt $u$ daar ook geen AOW-rechten op. Dit betekent dat $u$ al een stukje pensioen gaat missen. Voor de periode dat $u$ gedetacheerd was in Duitsland is ervoor gekozen om pensioenopbouw voort te zetten in Nederland. Hiervoor gelden ook aparte fiscale regels. Vanaf het moment dat $u$ vervolgens terugkeert in Nederland hervat $u$ de opbouw van AOW-rechten alsook de opbouw van het aanvullend pensioen maar dan volgens de Nederlandse civiele en fiscale regelgeving tot het moment waarop $u$ verhuist naar België. Vanaf dat moment stopt wederom de opbouw van AOW-rechten en bent $u$ slaper geworden in het Nederlandse pensioenfonds omdat $u$ in België niet op basis van detachering gaat werken. Vanwege $u$ werkzaamheden bij de Belgische werkgever gaat $u$ aldaar krachtens wet Rustpensioen opbouwen alsook het wettelijk geregeld aanvullend pensioen, waarvoor $u$ premies Rijksbijdrage Sociale Zekerheid (RSZ) betaalt. Voor alle genoemde pensioenvormen gelden andere civiele en fiscale regels. Op basis van nationale wetgeving kunnen fiscale faciliteiten toegekend worden, maar dit wil niet automatisch zeggen dat deze fiscale faciliteiten ook toegekend worden voor de grensoverschrijdende situaties.

Gelet op deze korte weergave van consequenties en opkomende vragen moge het belang van een grensoverschrijdend pensioenregister dat de achterliggende fiscale aspecten in acht neemt, duidelijk zijn.

De functie van het grensoverschrijdende pensioenregister is dus om een totaal overzicht en inzicht te geven met betrekking tot de opgebouwde pensioenrechten. Raadpleging van het register laat zien welke pensioenen van wie ontvangen wordt alsook op welk moment. Nu de pensioenleeftijden in Europa niet gelijk zijn, zullen de pensioenen op verschillende momenten aanvangen met de uitkering.

Wat de fiscaliteit betreft vraagt dit alles om een nauw luisterende bewerking achter de schermen. Voor de pensioenen binnen één land is het wat makkelijker aan te geven wat de omvang van een netto pensioen zal zijn, maar in deze situatie hebben we te maken met iemand 
die in het ene land woont en uit dat land en andere landen pensioen gaat ontvangen. Er zal gekeken moeten worden welke nationale fiscale regels hiervoor gelden en welke afspraken tussen de betreffende landen zijn gemaakt in de belastingverdragen ter voorkoming van dubbele belasting. Met de juiste methodiek moet het mogelijk zijn de gebruiker van het grensoverschrijdende pensioenregister te informeren over zijn netto te besteden pensioen uit alle drie de landen en de bijbehorende ingangsmomenten. In het promotieonderzoek van Sander Kramer richten we ons op fiscale methodiek en proberen we tot een grensoverschrijdend fiscaal model voor België, Nederland en Duitsland te komen dat ook dienstbaar kan zijn voor andere Europese landen en waarbij tevens rekening wordt gehouden met de gedragseconomische componenten om de bewustwording bij de burger te vergroten. Het grensoverschrijdende pensioenregister is bij uitstek de grensoverschrijdende organisatie van fiscaal pensioen.

\section{Grensoverschrijdende fiscale pensioenkwalificatie}

Het organiseren van grensoverschrijdend fiscaal pensioen gaat echterverder en vraagt ook om beleidsmatige sturing en verbetering. Ik heb zojuist in algemene bewoordingen gesproken over wettelijk pensioen en aanvullend pensioen. In sommige situaties heb ik bepaalde pensioenvormen concreet met naam genoemd zoals het Rustpensioen, de Rentenversicherung en de AOW. Op hoofdlijnen zijn bepaalde pensioenvormen vergelijkbaar met elkaar en lijkt een onderscheid gemaakt te kunnen worden tussen pensioenen die onder de noemer sociale zekerheid zijn te plaatsen en de pensioenen die daarbuiten vallen. Voor de eerste soort van pensioenen is in beginsel de Verordening $883 / 2004^{30}$ ingevolge de coördinatie van sociale zekerheidsstelsels van toepassing en met betrekking tot de overige aanvullende pensioenen wordt vanuit Europees perspectief veelal een aansturing gegeven vanuit bepaalde pensioenrichtlijnen. ${ }^{31}$ Met betrekking tot de bepaling van de reikwijdte van deze richtlijnen is hierin opgenomen dat de richtlijn werking heeft voor zover de pensioenen niet onder de reikwijdte van de sociale zekerheidsverordeningen vallen.

30 Verordening (EG) Nr. 883/2004 van het Europees Parlement en de Raad van 29 april 2004 betreffende de coöradinatie van de socialezekerheidsstelsels, zie ook Verordening (EEG) nr. 1408/71 van de Raad van 14 juni 1971 betreffende de toepassing van de socialezekerheidsregelingen op werknemers en zelfstandigen, alsmede op hun gezinsleden, die zich binnen de Gemeenschap verplaatsen

31 Zie bijv. Richtlijn 98/49/EG van de Raad van 29 juni 1998 betreffende de bescherming van de rechten op aanvullend pensioen van werknemers en zelfstandigen die zich binnen de Gemeenschap verplaatsen, Richtlijn 2003/41/EG van het Europees Parlement en de Raad van 3 juni 2003 betreffende de werkzaamheden van en het toezicht op instellingen voor bedrijfspensioenvoorziening (IORP I-richtlijn), Richtlijn 2014/50/EU van het Europees Parlement en de Raad van 16 april 2014 betreffende minimumvereisten voor de vergroting van de mobiliteit van werknemers tussen de lidstaten door het verbeteren van de verwerving en het behoud van aanvullende pensioenrechten (Mobiliteitsrichtlijn). 
Hiermee lijkt een duidelijk onderscheid gemaakt te kunnen worden tussen de wettelijke pensioenen enerzijds en de aanvullende pensioenen anderzijds, ware het niet dat de fiscaliteit zich niet specifiek conformeert aan de ene dan wel de andere afbakening.

Binnen nationale verhoudingen werken de genoemde afbakeningen wel, maar dat geldt niet meer voor de grensoverschrijdende situaties. leder land hanteert namelijk zijn eigen criteria om te bepalen wat wettelijk pensioen is en wat aanvullend pensioen. Daaraan gekoppeld zit de autonome bevoegdheid van ieder land om zijn eigen fiscale wet- en regelgeving te verbinden.

Wanneer we inzoomen op deze specifieke criteria per land blijkt dat pensioen voor de toepassing van fiscale wet- en regelgeving verschillend gekwalificeerd wordt. Zo kan een pensioenvorm in het ene land gekwalificeerd worden als een wettelijk pensioen uit de eerste pijler, terwijl de kenmerken van dat pensioen zodanig vergelijkbaar zijn met een pensioenvorm uit het andere land dat het aldaar gezien zou worden als een aanvullend pensioen uit de tweede pijler.

Als voorbeeld kan genoemd worden de Rentenversicherung van ons buurland Duitsland. Deze pensioenvoorziening wordt van overheidswege geregeld en valt onder de werking van de sociale zekerheidsregels van Vo. 883/2004 en kwalificeert als een wettelijk pensioen uit de eerste pijler. Kenmerkend voor dit pensioen is echter ook dat opbouw alleen mogelijk is wanneer een arbeidsrelatie aantoonbaar is.

Als we dit afzetten tegen de criteria die in Nederland gehanteerd worden om het onderscheid te duiden tussen de eerste pijler met daarin de AOW en de tweede pijler met daarin het aanvullende werknemerspensioen, dan blijkt dat we in Nederland anders aankijken tegen de rol van arbeid in relatie tot de oudedagsvoorzieningen in de eerste en tweede pijler. Vervolgens verbinden we daar in Nederland onze eigen fiscale consequenties aan vast. En zo doet Duitsland dat ook.

Op het moment dat een mobiele werknemer over de grens gaat werken, loopt hij tegen deze fiscale pensioenkwalificatieproblematiek aan.

Stel $u$ wordt voor de duur van drie jaar gedetacheerd bij een Duitse werkgever. $U$ doet er verstandig aan om gedurende de periode van 
detachering uw pensioenregeling in Nederland voort te zetten. Hierover moet weliswaar afspraken gemaakt worden met de Duitse werkgever aangezien het werkgeversdeel van de premielast op hem komt te drukken, maar voor $u$ is het voordeel dat $u$ in ieder geval weet dat er een verdere pensioenopbouw plaatsvindt. Nu u maar voor drie jaar gedetacheerd wordt in Duitsland is op voorhand bekend dat $u$ niet de vereiste vijf jaar haalt om in aanmerking te komen voor definitief verworven pensioenrechten. Bovendien bouwt $u$ geen AOW-rechten op in de periode dat $u$ in Duitsland woont en werkt. Nu u als gedetacheerde werknemer in Duitsland woont, bent $u$ voor dat land binnenlands belastingplichtige geworden en is de Duitse belastingwetgeving op $u$ van toepassing. En hier loopt $u$ tegen de fiscale vraag in hoeverre de Nederlandse pensioenregeling bekend is en aangemerkt kan worden als een pensioenregeling die 'over het algemeen gelijkwaardig' is met een Duitse fiscaal erkende pensioenregeling.

Zou $u$ in Nederland zijn blijven wonen en werken, dan was op uw pensioenopbouw de fiscale omkeerregel van toepassing gebleven. In de opbouwfase worden hierbij de pensioenaanspraken van de werkgever vrijgesteld en is het werknemersdeel van de premie aftrekbaar. Belastingheffing vindt vervolgens pas plaats bij de pensioenuitkering.

In Duitsland wordt deze omkeerregel in beginsel niet toegepast op de Nederlandse pensioenregeling die door een gedetacheerde werknemer wordt voortgezet, tenzij op grond van het nieuwe belastingverdrag tussen Nederland en Duitsland voldaan wordt aan de voorwaarden zoals opgenomen in de non-discriminatiebepaling van het verdrag. ${ }^{32}$ Als eerste voorwaarde wordt gesteld dat de werknemer al moest deelnemen in de pensioenregeling voordat hij de dienstbetrekking aanvaardde in de nieuwe werkstaat. Als tweede voorwaarde geldt dat de bevoegde autoriteit van het gastland, in dit geval Duitsland, moet vaststellen dat de fiscale vermindering voor de pensioenregeling over het algemeen gelijkwaardig is aan de fiscale vermindering voor een door deze staat, Duitsland dus, voor de belastingheffing als zodanig erkende pensioenregeling. Onder 'over het algemeen gelijkwaardig' zijn moet verstaan worden dat de fiscale vermindering voor de desbetreffende pensioenregeling op hoofdlijnen bezien overeenkomt met de fiscale vermindering voor een door de werkstaat, Duitsland, fiscaal erkende pensioenregeling. 
Hoewel deze toevoeging in het belastingverdrag een verbetering is omdat hiermee de toegang tot het benutten van fiscale faciliteiten wordt geopend, blijft het een subjectieve invulling wat verstaan moet worden onder 'over het algemeen gelijkwaardig'.

Uiteraard biedt dit aan de ene kant bewegingsruimte, maar aan de andere kant moet vastgesteld worden dat een objectief vastgesteld kader ontbreekt dat handvatten kan geven voor een uniforme beoordeling.

Bij een negatieve beoordeling kan de pensioenopbouw weliswaar voortgezet worden, maar zonder dat hiervoor fiscale faciliteiten toegekend of erkend worden. De pensioenopbouw vindt dan in de belaste sfeer plaats. Tegen de tijd dat de pensioenuitkeringen gedaan worden, zullen de uitkeringen die toe te rekenen zijn aan de detacheringsperiode belast worden. Dat betekent derhalve een dubbele belastingheffing.

Kijken we bijvoorbeeld naar de Nederlandse belastingwetgeving dan wordt er vervolgens in zo'n situatie wel een uitweg geboden om die dubbele heffing te voorkomen, maar het is dan de belastingplichtige die dan aannemelijk moet maken dat over de betreffende pensioenaanspraken al een heffing naar het inkomen heeft plaatsgevonden die naar aard en strekking overeenkomt met de loonbelasting of de inkomstenbelasting. ${ }^{33}$ En ook hier zien we weliswaar welwillendheid, maar een terminologie als 'naar aard en strekking' ontbeert enige aantoonbare objectiviteit en uniformiteit. Enkel door individueel handelen van de belastingplichtige kan dan aangetoond worden of een dergelijke pensioenregeling reeds fiscale faciliteiten ondervonden heeft waarna de correcte fiscale behandeling toegepast kan worden.

Wanneer de arbeidsmobiliteit in Europa bevorderd moet worden, moeten dit soort handelingen op individueel niveau voorkomen worden. Dit vraagt om een structurele en gemeenschappelijke aanpak op een hoger niveau. Nu het hier om fiscale maatregelen gaat die onder de autonomie van een land valt, kan dit niet zomaar op Europees niveau beslist worden. Om die reden moeten de oplossingen gezocht worden in andere lagen.

Als we bijvoorbeeld naar Nederland kijken, worden er al verschillende acties ondernomen om in ieder geval helderheid te creëren en in

33 Zie art. 1.7, lid 2, onderdeel c jo. art. 3.82, onderdeel b en art. 3.82, onderdeel c Wet op de inkomstenbelasting 2001 (Wet IB 2001). 
sommige gevallen ook concrete wederzijdse toepassingen. In de notitie Nederlands Fiscaal Verdragsbeleid is in ieder geval opgenomen dat Nederland bij nieuwe verdragen ter voorkoming van dubbele belasting ernaar streeft de opname van een regeling inzake voortgezette pensioenpremieaftrek in het non-discriminatieartikel op te nemen. ${ }^{34}$

Voor de situaties waarbij in deze geen afspraken zijn vastgelegd in bilaterale belastingverdragen hanteert Nederland een eenzijdige fiscale tegemoetkoming dat is vastgelegd in het besluit internationale aspecten van pensioenen en stamrechten. 35

Wanneer een Franse werknemer voor een paar jaar in Nederland wordt gedetacheerd en zijn Franse pensioenregeling wenst voort te zetten, wordt deze Franse pensioenregeling in Nederland fiscaal erkend en krijgt deze Franse werknemer in Nederland dezelfde fiscale tegemoetkoming als welke hij ook genoten zou hebben wanneer hij in Frankrijk was blijven wonen en werken. Ook wordt in Nederland gewerkt met besluiten waarin de fiscale behandeling is opgenomen met betrekking tot bepaalde buitenlandse sociale zekerheidsstelsels, omdat er bepaalde overeenkomsten bestaan met de pensioenregeling zoals wij die in Nederland in de tweede pijler tegenkomen. ${ }^{36}$ Vanwege het feit dat het overheersende karakter van die buitenlandse sociale zekerheidsregeling dat van een Nederlands tweede pijlerpensioen is en de regeling qua resultaat niet overtreft hetgeen onder het Nederlandse systeem is toegestaan, is op die regeling ook de omkeerregel van toepassing als ware het een zuivere pensioenregeling.

Echter ook hier dient opgemerkt te worden dat de fiscale tegemoetkoming toegekend wordt vanwege het 'overheersende karakter' en dat de regeling binnen de Nederlandse fiscale normen blijft. Een onderbouwing op basis van objectieve criteria is er niet hoewel niet ontkend kan worden dat uniformiteit nagestreefd wordt.

Hetgeen ik hier aangeef zijn enkel inspanningen die vanuit Nederland plaatsvinden, maar die niets zeggen over de handelswijze van andere landen. In vergelijking met de andere landen is Nederland wel vooruitstrevend op dit terrein.

34 Ministerie van Financiën, Notitie Nederlands fiscaal verdragsbeleid, 11 februari 2011, par. 2.11.5.

35 Besluit van 9 oktober 2015, inzake internationale aspecten van pensioenen en stamrechten, $\mathrm{nr}$. DGB2015/7010M.

36 Besluit buitenlandse sociale verzekeringen, Duitse, Belgische en Luxemburgse sociale zekerheid, aftrek premie en belastbaarheid uitkeringen, 24 maart 2014, nr. DGB 2014/144M, Mededeling Internationaal belastingrecht, Fiscale kwalificatie buitenlandse socialezekerheidsstelsels, 5 januari 2016, DGB 2016/20. 
De uitdaging die er ligt, is hoe we dit naar een hoger plan kunnen tillen en binnen Europa tot een grensoverschrijdend fiscaal pensioenbeleid kunnen komen die de arbeidsmobiliteit van in- en uitgaande werknemers faciliteert, die de ruimte geeft tot een adequate pensioenopbouw, al dan niet in de vorm van voortzetting van de oors pronkelijke pensioenregeling, en waarbij geen fiscale belemmeringen ontstaan. Aansluiting zoeken bij criteria die door het Europese Hof van Justitie geformuleerd zijn, biedt onvoldoende sturing nu het hof enkel beziet of sprake is van een regeling die voortkomt uit een wettelijke regeling die onder de reikwijdte van de verordening inzake sociale zekerheid valt of niet. Aangezien de fiscaliteit buiten de materiële werkingssfeer van zowel de genoemde sociale zekerheidsverordeningen als de pensioenrichtlijnen valt, is in deze rechtspraak onvoldoende aanknopingspunten te vinden.

$\mathrm{Nu}$ de pensioenstelsels in alle landen zo divers zijn en harmonisatie op dat vlak niet aan de orde is, zal de oplossing in de faciliterende regelingen gezocht moeten worden. Door middel van enige organisatie zou er wel vanuit de Europese Commissie sturing gegeven kunnen worden om fiscaal beleid zo veel mogelijk op elkaar af te stemmen. De Europese Commissie heeft dat immers eerder ook al gedaan door het uitbrengen van een Mededeling in 2001.37

De meeste lidstaten gaan al uit van een EET-systeem en zijn in zoverre vergelijkbaar. In Nederland spreken we in dit verband fiscaal over de eerder genoemde omkeerregel waarbij de opbouwfase onbelast is en de pensioenuitkeringen in de heffing worden betrokken. In internationaal verband komt het belastingpensioensysteem tot uitdrukking door met de letters $\mathrm{E}$ of $\mathrm{T}$ aan te geven of een bepaalde fase in het pensioentraject belast is of vrijgesteld. Daarbij onderkennen we drie fases, namelijk de opbouwfase waarin de pensioenpremies betaald worden, de rendementsfase waarin rendement behaald wordt met de ingelegde gelden en tenslotte de uitkeringsfase waarin het pensioen uitbetaald wordt aan de pensioengerechtigde.

De omkeerregel zoals toegepast in Nederland wordt in internationaal verband aangemerkt als een EET-systeem. De opbouwfase en investeringsfase zijn beide onbelast, dus twee keer de letter $\mathrm{E}$ en de uitkeringsfase is belast en heeft dus de letter T.

37 Mededeling van de Commissie aan de Raad, het Europees Parlement en het Economisch en Sociaal Comité, De opheffing van fiscale barrières voor grensoverschrijdende bedrijfspensioenregelingen, $\mathrm{COM} / 2001 / 0213$ def. 
Binnen de Europese Unie zijn er 18 lidstaten die het EET-systeem hanteren, waaronder België, Frankrijk, Portugal en Finland. ${ }^{38}$ Daarnaast zijn er nog vijf landen die het ETT-systeem toepassen, waaronder Denemarken, Cyprus en Zweden.39 Kenmerkend voor deze 23 landen is dat de pensioenuitkeringen naar nationaal belastingrecht in de belastingheffing betrokken worden. Slechts een viertal landen, waarvan Duitsland een dubbele rol heeft, hanteren het TEE-systeem. Het betreft hier verder nog Luxemburg, Hongarije en Polen. In deze landen worden de uitkeringen niet in de heffing betrokken.

Vergelijkbare EET-systemen zijn mijns inziens een pre om in ieder geval vanuit eenzelfde uitgangspunt te starten, maar zijn echter niet genoeg om grensoverschrijdende pensioenactiviteiten zonder belemmeringen te laten verlopen, omdat op detailniveau te veel afwijkingen bestaan. Om die reden pleit ik ervoor in ieder geval binnen Europa tot een wederzijdse fiscale erkenning van de buitenlandse pensioenregeling te komen waarbij aan de hand van objectieve criteria bepaald kan worden wat onder een dergelijke pensioenregeling verstaan kan worden. Door een uniforme Europees erkende aanpak, zou op deze wijze een bijdrage geleverd kunnen worden aan de grensoverschrijdende arbeidsmobiliteit.

In het promotieonderzoek van Bastiaan Didden wordt dan ook onderzocht in hoeverre het mogelijk is om tot gemeenschappelijke pensioenkenmerken te komen op basis waarvan het voor fiscale doeleinden mogelijk is onderscheid te maken tussen enerzijds de pensioenen voortkomend uit de sociale zekerheid en anderzijds de aanvullende pensioenen. In dit onderzoek is de focus aangebracht op België, Nederland en Duitsland, met dien verstande dat het beoogde format en de beoogde resultaten ook voor andere landen in Europa toegepast moeten kunnen worden.

\section{Grensoverschrijdende fiscale kwalificatieproblematiek ook in andere context}

De pensioenkwalificatieproblematiek doet zich overigens niet alleen voor wanneer een werknemer grensoverschrijdend wil gaan werken of van zijn pensioen wil gaan genieten. De vraagstelling doemt ook op wanneer gehuwden besluiten te gaan scheiden en daarbij pensioen dat in het buitenland is opgebouwd in de verdeling moet gaan betrekken.

38 Landen in de EU met EET-systeem: België, Bulgarije, Duitsland (deels nog TEE), Estland, Griekenland, Spanje, Frankrijk, Letland, Litouwen, lerland, Nederland, Oostenrijk, Portugal, Roemenië, Slovenië, Slowakijke, Finland en het Verenigd Koninkrijk.

39 Landen in de EU met ETT-systeem: Tsjechië, Denemarken, Italië, Cyprus en Zweden. 
Laten we terugkeren naar mijn eerder aangehaald voorbeeld waarbij $u$ eerst een tijdje in Nederland heeft gewerkt, vervolgens voor drie jaar gedetacheerd wordt bij een Duitse werkgever en ook in Duitsland gaat wonen. Vervolgens verhuist $u$ terug naar Nederland, maar aanvaardt dan een dienstbetrekking in België en gaat daar wonen en werken. $\mathrm{Na}$ een aantal jaren keert $u$ toch terug naar Nederland. Er is dan op verschillende plekken pensioen opgebouwd. Uw partner en $u$ hebben besloten te gaan scheiden. De vraag komt op welke pensioenen verdeeld moeten worden en wat zijn daarvan de fiscale consequenties. Zouden we al een grensoverschrijdend pensioenregister hebben, dan zou snel te overzien zijn welke pensioenaanspraken waar opgebouwd zijn. Helaas zal dus eerst met de diverse buitenlandse pensioenuitvoerders contact opgenomen moeten worden om te achterhalen welke pensioenaanspraken opgebouwd zijn die eventueel voor verdeling in aanmerking komen.

Eventueel, want ook hier komen de pensioenkwalificatievragen in beeld. Vanwege de echtscheiding moet $u$ uw pensioen gaan verevenen op grond van de Wet verevening pensioenrechten bij scheiding. Volgens deze wet dienen de pensioenen die bij of via een Nederlandse werkgever zijn opgebouwd verevend te worden. Dat is dus ook het pensioen dat toe te rekenen is aan de Duitse detacheringsperiode. $U$ heeft geen Duitse pensioenrechten opgebouwd, dus daarin hoeft niets gedeeld te worden. Dat is anders voor het Belgische pensioen. Om de vraag te beantwoorden of dit Belgische pensioen verevend moet worden volgens de Nederlandse wetgeving dient eerst vastgesteld te worden of het huwelijk is gesloten onder het Nederlandse recht. Wanneer daarvan sprake is geldt als regel dat een pensioen ingevolge een buitenlandse pensioenregeling ook onder de werking van de wet valt en er dus verevening moet plaatsvinden.

Wat echter verstaan moet worden onder een pensioen ingevolge een buitenlandse pensioenregeling is niet duidelijk. Komen de opgebouwde rechten ingevolge het Rustpensioen nu wel of niet voor verevening in aanmerking? Hier blijkt wederom het belang om tot uniforme kwalificatiekenmerken te komen. Daarmee hebben we het eerste deel van de problematiek te pakken. Het tweede deel ziet vervolgens op de fiscale consequenties. Als er sprake is van een buitenlands pensioen dat in de verevening betrokken moet worden, zal pas op pensioeningangsdatum het pensioen tot uitkering komen vanuit het buitenland. Daarbij 
dient nagegaan te worden met inachtneming van het bepaalde in de belastingverdragen wie al dan niet in de heffing betrokken worden en in hoeverre tegemoetkomingen genoten kunnen worden en of door de fiscale toepassing de belastingdruk wel op de juiste personen komt te rusten. In het promotieonderzoek van Bas Vereggen kijken we op welke wijze de grensoverschrijdende fiscale consequenties van pensioendeling bij echtscheiding beter gestructureerd kunnen worden.

Behalve de zojuist genoemde problematiek, zien we de problematiek van kwalificatie ook op andere plekken binnen de fiscaliteit naar voren komen. Bijvoorbeeld de kwalificatie van een pensioeninstelling voor de toepassing van de Wet op de dividendbelasting in verband met de teruggave van dividendbelasting, ${ }^{40}$ maar ook de BTW-kwalificatie van een pensioenfonds als gemeenschappelijk beleggingsfonds waardoor sprake is van vrijgestelde diensten, hetgeen tot hogere uitvoeringskosten in de pensioensector leidt. ${ }^{41}$ ledere keer wordt gezocht naar voorwaarden en kenmerken voor een goed toepasbare pensioenkwalificatie om op die manier zonder belemmeringen te kunnen werken. Het moge duidelijk zijn dat op het terrein van de kwalificatie van pensioen en de daaruit voortkomende consequenties nog veel te doen is. Het aanbrengen van structuur is daarbij mijns inziens dan ook zeer wenselijk.

\section{Fiscale grenseffectentoetsing bij pensioenwetgeving}

Met het kwalificeren van pensioen bereiken we meer structuur en inzicht en kunnen we nieuwe fiscale wet- en regelgeving daar veel beter op afstemmen. Daarin ligt een volgende uitdaging. Mijns inziens is het de taak van de wetgever om bij het maken van nieuwe wetgeving niet alleen te beoordelen wat de consequenties zullen zijn in nationale verhouding en of het Europeesrechtelijk toelaatbaar is, maar dient ook getoetst te worden wat de fiscale grenseffecten zullen zijn.

Hoewel enige bewustwording over het belang hiervan wel leeft, ziet het er voorlopig nog niet naar uit dat een grenseffectentoetsing vast onderdeel wordt van het wetgevingstraject. ${ }^{42}$

40 Zie bijv. HvJ EU 6 oktober 2011, nr. C-493/og (Commissie/Portugal), HvJ EU 8 november 2012, nr. C-342/10 (Commissie/Finland), HvJ 2 juni 2016, nr. C-252/14 (Pensioenfonds Metaal en Techniek/ Skatteverke

41 Zie bijv. HvJ EG/EU 13 maart 2014, C-464/12 (ATP), HvJ EU 9 december 2015, nr. C-595/13, Conclusie A-G Ettema 23 februari 2016, nr. 15/00148, NTFR 2016/1069

42 Brief van minister van Economische Zaken, Grensoverschrijdende samenwerking op het gebied van economie en arbeid, 17 juli 2015, DGBI / 15093988. 
Om gemiste kansen te voorkomen, maar ook om al in het voortraject zichtbare belemmeringen te kunnen duiden, zal ik de komende jaren de fiscale grenseffecten onderzoeken en toetsen van voorgestelde alsook van recente ingevoerde wet- en regelgeving binnen het pensioendomein. Daarin wordt meegenomen de grensoverschrijdende kwalificatie als pensioen en de al dan niet toepasbaarheid van fiscale wet-en regelgeving in grensoverschrijdende situaties. Doelstelling van deze werkzaamheden is om risico's en kansen tijdig vast te stellen en op basis daarvan adequate beleidsaanbevelingen te kunnen doen die sturing kunnen geven dan wel tot bijstelling leiden van fiscale pensioenwetgeving ter optimalisatie van het grensoverschrijdend pensioenverkeer.

Kijk nu bijvoorbeeld naar het wetsvoorstel inzake de uitfasering van pensioenopbouw in eigen beheer. ${ }^{43}$ In lijn der verwachting zal met ingang van 1 januari 2017 het niet meer mogelijk zijn pensioen in eigen beheer op te bouwen. De directeur-grootaandeelhouder krijgt in het kader van de fiscale afwikkeling een aantal wegen voorgelegd die hij kan bewandelen. Hij kan ervoor kiezen de pensioenverplichting die voor commerciële waarde op de balans staat af te waarderen naar de fiscale waarde zonder dat dit fiscale consequenties heeft voor de loonbelasting of vennootschapsbelasting. Evenmin is hij dan revisierente verschuldigd. Of hij laat de pensioenverplichting op de balans staan en laat de opgebouwde pensioenaanspraken onder het nieuwe overgangsrecht vallen. Dit betekent dat de fiscale wetgeving zoals die luidt op 31 december 2016 van toepassing zal blijven.

De directeur-grootaandeelhouder die echter gekozen heeft voor de afwaardering van de pensioenverplichting moet vervolgens nog een keuze maken. Hij gaat over tot afkoop van zijn pensioenaanspraken of hij zet de afgewaardeerde pensioenverplichting tegen fiscale waarde om in een oudedagsverplichting. Om de afkoop van de pensioenaanspraken te stimuleren geldt de afkoopmogelijkheid slechts gedurende drie jaren en om het nog aantrekkelijker te maken hoeft de directeurgrootaandeelhouder in 2017 niet over 100\% van de fiscale waarde af te rekenen, maar krijgt hij een korting van 34,5\%. Indien hij wacht tot een jaar later is de korting nog maar $25 \%$ en in 2019 bedraagt de korting 19,5\%. De directeur-grootaandeelhouder die wellicht niet over voldoende liquiditeiten beschikt om de verschuldigde belasting te betalen, kan er

43 Wet uitfasering pensioen in eigen beheer en overige fiscale pensioenmaatregelen, TK 20162017 , nr. 34555 . 
ook voor kiezen om de pensioenverplichting tegen fiscale waarde om te zetten in een oudedagsverplichting. Door deze omzetting blijft het geld in de onderneming en behoudt de directeur-grootaandeelhouder een aanspraak voor de oude dag. Doteren voor een verdere opbouw is echter niet meer mogelijk. Bij het bereiken van de AOW-pensioengerechtigde leeftijd moet de reservering gedurende 20 jaar gelijkmatig worden uitgekeerd onder inhouding van loonbelasting of de directeurgrootaandeelhouder kiest voor de aankoop van een lijfrenteproduct. Het bijzondere van deze omzetting van pensioenaanspraken in een oudedagsverplichting is dat het pensioenkarakter verloren gaat. De oudedagsverplichting is niet meer dan een schuld op de balans. Er bestaat dan ook geen recht meer op toekomstige pensioenuitkeringen.

In het licht van de zojuist genoemde grenseffectentoets en kwalificatieproblematiek zien we dat de wetgever in de memorie van toelichting beperkt aandacht besteed aan de internationale of grensoverschrijdende aspecten van dit voorstel, terwijl over de verdragsrechtelijke context van dit nieuwe product toch iets te zeggen moet zijn. Onder de paragraaf 'EU-aspecten' wordt alleen aangegeven dat deze er niet zijn. ${ }^{44}$

Voor zover iets gezegd kan worden over het karakter van de oudedagsverplichting en de fiscale behandeling daarvan, is dat de uitkeringen fiscaal aangemerkt moeten worden als loon uit vroegere dienstbetrekking. Verder moet het tegoed over een zodanig lange periode worden uitgekeerd dat sprake blijft van een oudedagsvoorziening, aldus de wetgever. Er is dus duidelijk geen sprake meer van pensioen, hoewel door het gebruik van het woordje 'blijft' het lijkt alsof er een voortzetting is van een bestaande situatie.

De vraag die opkomt, is dus welke kwalificatie aan deze oudedagsverplichting gegeven moet worden voor verdragstoepassing. Deze vraag is later tijdens de parlementaire behandeling dan ook terecht gesteld. Er moeten immers fiscale gevolgen aan verbonden kunnen worden. Is het de bedoeling dat deze onder het verdragsartikel 'andere inkomsten' komt te vallen?

44 Wet uitfasering pensioen in eigen beheer en overige fiscale pensioenmaatregelen, TK 20162017, nr. 34 555, nr. 3, p. 20. 
Het 'pensioenartikel' in een verdrag lijkt mij niet te kwalificeren aangezien het niet meer om pensioen gaat. Het karakter is er immers heel bewust vanaf gehaald. Toch worden bijvoorbeeld alle sanctiebepalingen, inclusief de conserverende aanslag, die gelden voor pensioen van overeenkomstige toepassing verklaard op deze oudedagsverplichting. ${ }^{45}$ Bij de beantwoording van de Kamervragen blijkt dan ook dat de wetgever van mening is dat de oudedagsverplichting voor de verdragstoepassing onder het pensioenartikel moet vallen. Als verklaring wordt gegeven dat de directeur-grootaandeelhouder een opgebouwde aanspraak op uitkeringen heeft die bestemd zijn om te voorzien in de verzorgingsbehoefte van zijn oude dag. ${ }^{46} \mathrm{Om}$ die reden zou de oudedagsverplichting onder het pensioenartikel van de Nederlandse belastingverdragen moeten vallen. ${ }^{47}$ Hiermee komen we terug op de eerder door mij aangehaalde noodzaak om te komen tot objectieve criteria wat voor grensoverschrijdende situaties verstaan moet worden onder pensioen. Het is immers nog maar de vraag of een verdragspartner de oudedagsverplichting zonder meer accepteert als pensioen in de zin van het pensioenartikel in het verdrag. Het strekt in ieder geval tot aanbeveling dat in de notitie Nederlands Fiscaal Verdragsbeleid opgenomen wordt welke karakterisering gegeven dient te worden aan de oudedagsverplichting.

Ten slotte wil ik de introductie van de aftoppingsgrens van ruim $€ 100.000$ ( $€ 101.519$ in 2016) en het nettopensioen benoemen. Vanaf 2015 heeft dit werking gekregen. Het kabinet was oorspronkelijk van mening dat mensen met een inkomen boven de $€ 100.000$ zelf in staat zijn om met betrekking tot dit surplus zelf te sparen voor een aanvulling op het inkomen na pensionering. Een fiscale facilitering van pensioenopbouw boven een inkomensniveau van drie keer modaal wordt niet meer nodig geacht. Toch is hier onder druk een nuancering gekomen in de vorm van nettoproducten waarvoor een vrijstelling wordt verkregen in box 3 . Het nettopensioen is een arbeidsvoorwaardelijke afspraak, waarbij de werknemer ervoor kan kiezen om met dat deel van zijn salaris dat boven de aftoppingsgrens uitkomt deel te nemen aan deze regeling. De nettopensioenregeling heeft in beginsel de vorm van

45 Zie art. $38 p$, lid 4 Wet op de loonbelasting 1964 (nieuw).

46 De discussie die gevoerd kan worden dat de wetgever met twee maten meet nu de oudedagsverplichting in geval van echtscheiding niet als pensioen kwalificeert en om die reden niet voor verdeling in aanmerking komt, blijft omwille van de tijd hier buiten beschouwing.

47 Wet uitfasering pensioen in eigen beheer en overige fiscale pensioenmaatregelen, TK 20162017 , nr. 34555 , nr. 5, p. 14. 
een zuivere Defined Contribution-regeling zonder rendementsgarantie. Dit betekent dat pas op het moment waarop het kapitaal wordt omgezet in een aanspraak, het voor de pensioengerechtigde duidelijk wordt wat de omvang van zijn pensioenuitkering zal zijn. De pensioenpremie voor dit nettopensioen wordt betaald uit het nettosalaris. De fiscale facilitering van de nettopensioenregeling bestaat dus niet uit de toepassing van de omkeerregel. De enige fiscale facilitering die er in dit verband is, is de box-3-vrijstelling mits voldaan is aan de voorwaarden. Zodra de nettopensioenregeling tot uitkering komt, zijn de uitkeringen onbelast.

Wanneer een werknemer besluit te verhuizen naar het buitenland eindigt de deelneming in de nettopensioenregeling en krijgt hij een premievrije aanspraak. De pensioenuitvoerder is vervolgens verplicht mee te werken aan de afkoop van dit nettopensioen. De fiscale wetgeving is zodanig vormgegeven dat deze afkoop kan plaatsvinden zonder fiscale consequenties.

Hoewel afkoop van pensioen normaliter niet wordt toegestaan omdat dit in strijd zou zijn met het verzorgingskarakter, wijkt de wetgever met betrekking tot het nettopensioen makkelijk af van dit principe. De afkoopmogelijkheid is een bewuste keuze van de wetgever om te voorkomen dat een belastingplichtige geconfronteerd wordt met een dubbele belastingheffing. Deze dubbele heffing kan zich namelijk voordoen wanneer het andere land op basis van zijn heffingsbevoegdheid de uitkeringen gaat belasten, terwijl deze werknemer geen aftrek heeft genoten voor de ingelegde premies.

Voor degene die gaat emigreren heeft de wetgever een tegemoetkoming in de wet ingebouwd. De grensarbeider heeft hij echter vergeten. De in het buitenland wonende grensarbeider die nettopensioen heeft opgebouwd in Nederland gaat vanaf de pensioengerechtigde leeftijd van zijn pensioen genieten. Ook het nettopensioen zal dan tot uitkering komen, want de grensarbeider kan geen gebruik maken van de afkoopfaciliteit zoals opgenomen in de wet. Deze bepaling kan immers alleen ingeroepen worden wanneer sprake is van emigratie. Nu de grensarbeider al in het buitenland woont, doet zich emigratie niet voor en kan hij dus niet voldoen aan de voorwaarden.

Consequentie is dat op grond van het belastingverdrag ter voorkoming van dubbele belasting gekeken moet worden welk land heffingsbevoegd 
is. Zowel in het belastingverdrag met België als met Duitsland is een geclausuleerde bronstaatheffing opgenomen. Dit lijkt soelaas te bieden ware het niet dat in het verdrag met België het de vraag is of de Belgische belastingautoriteiten de box 3 vrijstelling zullen accepteren als een faciliteit in de zin van het verdrag. In het verdrag met Duitsland leidt de systematiek van de verrekeningsmethode ertoe dat alsnog een dubbele heffing ontstaat. Dat is dus twee keer pech voor de grensarbeider; geen afkoopmogelijkheid en ook nog (economisch) dubbele heffing.

Oplossing voor dit knelpunt is om de afkoopmogelijkheid van het nettopensioen ook mogelijk te maken voor de grensarbeider. Hiervoor dient zowel de Pensioenwet als de Wet op de inkomstenbelasting 2001 aangepast te worden.

Consequentie hiervan is een verdere inbreuk op het Nederlandse principe dat afkoop van pensioen een niet geoorloofde handeling is omdat het indruist tegen het verzorgende karakter dat aan pensioen toegekend kan worden. Nu deze afkoopfaciliteit echter al bestaat voor degene die emigreert, zie ik niet wat er problematisch zou kunnen zijn wanneer de faciliteit ook aan de grensarbeider wordt toegekend.

Het feit dat een inbreuk wordt gemaakt op het principe van het afkoopverbod laat zien dat er beweging komt in het Nederlandse denken over wat pensioen is. Ik ben van mening dat het goed is te kijken naar de maatschappelijke ontwikkelingen in Nederland en buiten de landsgrenzen. Bijstelling van de opvattingen en uitgangspunten moet kunnen, mits goed onderbouwd. En hier kom ik op een heikel punt, namelijk de aantasting van de omkeerregel door de introductie van de aftoppingsgrens.

\section{Handhaven omkeerregel zonder aftopping}

Het verbaast mij met welk gemak het mogelijk is geweest om een inbreuk te maken op de omkeerregel. Deze fiscale methodiek bestaat al meer dan 100 jaar in Nederland, waarbij de belastingheffing perfect aansluit bij het feitelijke genietingsmoment. Pensioen kwalificeert als uitgesteld loon. Deverkregen pensioenaanspraken tijdens de opbouwfase worden direct ondergebracht bij de pensioenuitvoerder zonder dat de werknemer dan wel deelnemer daar beschikkingsbevoegdheid over heeft. Het verkrijgen van die pensioenaanspraken is een vorm van beloning voor het verrichten van arbeid. Nu de deelnemer niet 
aan zijn pensioenaanspraken kan komen, achtte de wetgever het reëel om gedurende deze opbouwfase dan ook geen belastingheffing te laten plaatsvinden. Pas op pensioeningangsdatum ontvangt de pensioengerechtigde zijn pensioenuitkeringen en geniet fiscaal gezien dan zijn uitgesteld loon. Om die reden wordt de pensioengerechtigde dan ook op dat moment in de belastingheffing betrokken.

Voor de pensioengerechtigde is dit niet vreemd, aangezien de belastingheffing aansluit bij de realiteit van feitelijke uitkeringen. Dit zou anders zijn wanneer een deelnemer gedurende de arbeidsfase belasting moet betalen over zijn pensioenaanspraken gedurende zo'n 35-40 jaar, waarbij hij niet aan het geld kan komen en hij bovendien het risico loopt dat hij wellicht maar drie jaar van zijn pensioenuitkeringen kan gaan genieten omdat hij na die drie jaar komt te overlijden. In dat geval heeft hij vele jaren de belastingdruk over inkomen gehad, waarvan hij zeker nog niet in volle omvang heeft kunnen genieten.

Nu schets ik hier een pijnlijk voorbeeld met een vroegtijdig overlijden, maar ook als we uitsluitend naar de uitgangspunten kijken, zal het op zijn minst toch een wenkbrauw de hoogte doen ingaan als $u$ zich realiseert dat een werknemer in Nederland verondersteld wordt gedurende 40 jaar pensioenaanspraken op te bouwen waarbij hij niet aan het geld kan komen, maar waarvoor hij wel tegen het progressieve tarief belast wordt, waarna vervolgens de pensioendatum bereikt wordt en de pensioengerechtigde gedurende zo'n 20 jaar pensioenuitkeringen ontvangt omdat dit de gemiddelde levensverwachting is. Om er nog een factor bovenop te doen, moet $u$ zich ook nog realiseren dat een pensioengerechtigde tijdens de arbeidsfase tegen een hoger tarief in de heffing wordt betrokken dan in de pensioenfase, vanwege het feit dat in de pensioenfase geen AOW-premie van 17,9\% meer verschuldigd is. Bijkomend leidt een dergelijke toepassing tot een nog grotere druk op de houdbaarheid van de verplichtstelling van pensioen in Nederland.

Toch heeft de wetgever gemeend een inbreuk te moeten maken op dit principe door per 1 januari 2015 een aftoppingsgrens van $€$ 100.000 te introduceren. Het voordeel van het introduceren van de aftoppingsgrens is dat daarmee een deel van de belastingopbrengsten in de tijd naar voren gehaald wordt. Immers de werknemers met een salaris boven de aftoppingsgrens houden meer salaris over en betalen daardoor meer belasting. 
Het gevaar van het introduceren van de aftoppingsgrens is dat veel makkelijker de hoogte van de aftoppingsgrens bijgesteld kan worden en dat zal niet naar boven zijn.

Een verder verlagen van de aftoppingsgrens kan wellicht aanlokkelijk klinken voor mensen met een korte termijnvisie, het leidt immers op korte termijn tot hogere belastingopbrengsten, maar heeft ook andere neveneffecten waarbij het de vraag is of daar ook bij stil gestaan is.

Voor de lange termijn is aftopping mijns inziens funest. Budgettair zal het nadelig uitpakken en de grensoverschrijdende mobiliteit zal bovendien nog meer gehinderd worden.

De wending die de Nederlandse fiscale wetgever maakt is in een aantal opzichten opmerkelijk. Wanneer het in grensoverschrijdend en Europees perspectief bekeken wordt, zijn er 23 lidstaten in de Europese Unie die het EET- danwel het ETT-systeem hanteren. Alleen Luxemburg, Hongarije en Polen vormen hierop een uitzondering en hanteren een TEE-systeem waarbij de pensioenuitkeringen onbelast blijven. Duitsland hanteerde in het verleden ook een TEE-systeem, maar bouwt geleidelijk aan zijn belastingpensioensysteem om tot een EET-systeem.

Om tot een optimale grensoverschrijdende pensioenopbouw te komen, heb ik eerder al aangegeven dat het een pre is wanneer landen met vergelijkbare belastingpensioensystemen werken. Uiteraard geldt dat ook zodra de pensioenuitkeringen grensoverschrijdend tot uitkering komen en op dat moment al dan niet in de heffing betrokken moeten worden in één van beide landen.

Zoals eerder aangegeven is er nog genoeg werk te doen om tot een heldere en werkbare grensoverschrijdende pensioenkwalificatie te komen. Aansluitende belastingpensioensystemen maken daarbij dan het grensoverschrijdende verkeer voor de belastingplichtige veel makkelijker om zich over de landsgrenzen heen te bewegen zonder tegen fiscale belemmeringen aan te lopen. Dus vanuit een Europees, internationaal en grensoverschrijdend perspectief bezien moet de Nederlandse wetgever zich niet door korte termijnpolitiek laten verleiden vanuit een EETsysteem in een TEE-systeem te glijden. 
Op dit moment wordt Nederland in de Melbourne Mercer Global Pension Index van 2016 nog geroemd om zijn pensioenstelsel en staat daarmee op de tweede plaats in de wereldranglijst. ${ }^{8}$ Als we kijken waarop getoetst wordt, zien we daarin drie kernpunten. De adequaatheid dan wel toereikendheid van pensioen, de duurzaamheid en de integriteit van het pensioenstelsel. De balans die in Nederland bestaat tussen het eerste pijlerpensioen, de AOW, dat op omslagbasis is gefinancierd en het tweede pijlerpensioen, het werknemerspensioen, dat op kapitaaldekkingsbasis is gefinancierd, zie je nauwelijks in andere landen. Overigens wel bij het pensioenstelsel in Denemarken waarbij ook opgemerkt kan worden dat dit land op de eerste plaats staat.

Tornen aan deze balans tussen eerste en tweede pensioenpijler is mijns inziens een misstap die we niet moeten maken. Door het introduceren van de aftoppingsgrens is daartoe wel een eerste handeling gezet en een eventuele verlaging maakt de aantasting alleen maar groter. Aftopping en een eventuele verlaging leidt tot minder premie-inleg bij de pensioenfondsen. Dit betekent dat pensioenfondsen met minder premievolume moeten gaan werken aan het kapitaliseren van pensioen. Naarmate er minder inleg is, daalt ook de omvang van het tweede pijlerpensioen. De collectiviteit wordt ermee verkleind.

Het tegenargument dat hier de mogelijkheid van het nettopensioen tegenover staat, kan mijns inziens geen opgeld doen. Deelnemen aan een nettopensioenregeling vindt plaats op vrijwillige basis. De werknemer heeft de keuze om een deel van zijn netto salaris als pensioenpremie in te leggen in de nettopensioenregeling bij het pensioenfonds, maar hij kan er ook voor kiezen zijn salaris voor andere doeleinden dan een oudedagsvoorziening te gebruiken. Een één-op-één omzetting zal niet aan de orde zijn en verkleint daarmee de groep van deelnemers in het tweede pijlerpensioen.

Bij een eventuele verlaging van de aftoppingsgrens creëert de wetgever alleen maar meer problemen. Naarmate de aftoppingsgrens lager wordt, zal het aantal werknemers die kiest voor voortzetting van pensioenopbouw maar dan in een nettopensioenregeling verhoudingsgewijs alleen maar meer afnemen ten faveure van een hoger maandelijks bestedingsbedrag. Aan de andere kant neemt het absoluut aantal deelnemers bij een verlaging van de grens wel toe want er zullen altijd mensen zijn die instappen als ze mee mogen doen. 
Hier komt echter meteen de vraag op of de nettopensioenvrijstelling zoals die nu opgenomen is in box 3 van de inkomstenbelasting budgettair wel houdbaar blijft. Een eventuele afschaffing van deze vrijstelling zal de aantrekkelijkheid van deelname aan een nettopensioenregeling niet bevorderen.

Bovendien is het de vraag of de werknemer die toch wil investeren in verdere pensioenopbouw dat wil doen bij het pensioenfonds waarin zijn gewone pensioen wordt opgebouwd, of dat hij misschien de voorkeur eraan geeft zijn oudedagsvoorziening verder op te bouwen door middel van een nettolijfrente. Hier kan hij immers zelf bepalen met welke verzekeraar hij in zee wil gaan. We zien hier dat bewegingen met betrekking tot de aftoppingsgrens ook de marktordening kan beïnvloeden en dat er hier een verschuiving van tweede naar derde pijler zou kunnen plaatsvinden. Hoewel vanuit Europees perspectief gestimuleerd wordt om meer mensen gebruik te laten maken van derde pijlerproducten zoals lijfrenten en soortgelijke voorzieningen, wordt daarmee niet beoogd om die opbouw ten koste te laten gaan van de tweede pijler maar moet het juist gaan om een complementaire werking.

Alles bij elkaar genomen wordt de druk op duurzaamheid van het pensioenstelsel juist verhoogd in plaats dat het verstevigd wordt. Rekening houdend met de demografische voorspellingen zoals die naar voren komen in het OECD-rapport 'Pensions at a Glance 2015' van een in omvang toenemende en qua leeftijd ouder wordende bevolking in combinatie met lage geboortecijfers die onder het gemiddelde ligt om van een stabiele bevolkingsomvang te spreken, ben ik van mening dat de Nederlandse wetgever in deze de verkeerde keuzes maakt binnen het fiscale pensioendomein. ${ }^{49}$

Uit onderzoeken is namelijk gebleken dat de ouderen afhankelijkheidsratio in de OECD landen, waaronder Nederland, zal oplopen. Met andere woorden een zware vergrijzingstop van gepensioneerde mensen in relatie tot de werknemers in de arbeidsfase. Vanuit fiscaal en budgettair oogpunt zou gelet op de lange termijn juist vastgehouden moeten worden aan de EET-systematiek zonder aftopping.

Rekening houdend met de financierbaarheid van het pensioenstelsel zou juist de belastingheffing moeten blijven bij deze grote groep van 
pensioengerechtigden. Dit argument wordt nog meer versterkt wanneer ook de ontwikkeling van de geboortecijfers wordt meegenomen. In Nederland worden te weinig kinderen geboren om de stabiliteit in de bevolkingsomvang te behouden..$^{50}$ De achterblijvende geboortecijfers in combinatie met de ouderen afhankelijkheidsratio laten zien dat er een enorme druk zal ontstaan op de werkzame bevolking. Plaatsen we dit tegen de cijfers van de United Nations die berekend hebben dat we in 2050 op wereldniveau al te maken hebben met de situatie dat de groep ouderen van 65 jaar en ouder vanaf dat moment groter zal zijn dan de groep jongeren onder de leeftijd van 15 jaar, dan benadrukt dit des te meer het belang om met grensoverschrijdende aspecten rekening te houden alvorens fundamentele keuzes te maken en wijzigingen aan te brengen. ${ }^{51}$

Volgens mij kunnen we hier op zijn minst drie duidelijke conclusies uit trekken. Ten eerste is het van overheidswege budgettair noodzakelijk om gelet op de demografische ontwikkelingen de omkeerregel te blijven toepassen, waarbij dan tevens recht gedaan wordt aan de inkomensuitstelgedachte. Ten tweede laten deze gegevens zien dat dit pensioenbelastingsysteem meer waarborg geeft ten aanzien van de duurzaamheid en financiële houdbaarheid van de tweede pijlerpensioenen. Ten derde bevordert dit pensioenbelastingsysteem de grensoverschrijdende mobiliteit en migratiemogelijkheden die nodig zijn voor de duurzaamheid van het Nederlandse pensioenstelsel.

Dames en heren, ik kom nu tot een afronding. Ik heb $u$ meegenomen in het pensioenlandschap met haar vele dimensies. Ik heb $u$ laten zien dat ik in de komende jaren aan de hand van een aantal uitgangspunten wil werken aan de verbetering en optimalisering van het grensoverschrijdende fiscale pensioenverkeer. Dit vraagt in velerlei opzichten om organisatie, zowel op beleidsmatig als uitvoerend vlak. Niet alleen door mij, maar ook door de pensioensector, de overheden, de wetgever en beleidsmakers. Ik kijk ernaar uit daar mijn steentje aan bij te dragen.

50 In Nederland was de vervangingsratio 1,68 kind per vrouw, terwijl 2,1 kind per vrouw ziet op een stabiele bevolkingsomvang.

51 Zie http://www.un.org/en/development/desa/population/publications/ageing/WPA2O15_Infochart.shtml 


\section{Dankwoord}

Alvorens mijn rede volledig af te ronden, is dit het moment om een paar dankwoorden uit te spreken. Hoewel er veel mensen zijn aan wie ik mijn dank zou willen uitspreken, wil ik dit toch maar beperkt doen. Beperkt niet alleen omwille van de tijd, maar zeker omdat ik niemand zou willen vergeten.

In de eerste plaats wil ik het College van Bestuur van de Universiteit Maastricht en het Bestuur van de Faculteit der Rechtsgeleerdheid bedanken voor het in mij gestelde vertrouwen dat ik deze bijzondere leerstoel mag bekleden.

Mijn dank wil ik ook uitspreken aan al mijn collega's van de Capaciteitsgroep Belastingrecht en mijn collega's van ITEM. Met groot genoegen en veel plezier werk ik met jullie samen. Jullie zijn mijn basis. Ik dank jullie voor jullie vertrouwen, steun en de interesse die jullie tonen in mijn activiteiten.

In het bijzonder wil ik mijn dank richten aan Prof. dr. Hildegard Schneider, decaan van de rechtenfaculteit. Beste Hildegard, jouw persoonlijke betrokkenheid, steun en oprechte interesse in mij, mijn vakgebied en mijn ideeën waardeer ik ten zeerste.

Een groot woord van dank aan Prof. dr. Roland Brandsma die, behalve een goede vriend, voor mij een goede leermeester is. Beste Roland, samenwerken met jou is voor mij één grote leerschool. Ik dank je voor het delen van je gedachten, je inzichten en je eerlijke feedback.

Ten slotte richt ik mij tot jullie, Rogér, Raoul en Robin. Ik heb mij afgevraagd hoe ik jullie nu met alle égards moet bedanken voor alles wat jullie voor me doen en alle opofferingen die jullie voor mij over hebben. Ik prijs mij heel gelukkig met zo'n mooi gezin. Dank je Rogér, dank je Raoul en dank je Robin dat jullie er voor mij zijn.

Ik heb gezegd. 
